\title{
Article \\ Evaluation Process of the Burglary Resistance When Explosives Are Used to Create an Opening in the Barriers
}

\author{
Zuzana Zvakova *(D), Martin Boros $\mathbb{(}$, Lucia Figuli $(\mathbb{D}$ and Andrej Velas $\mathbb{1}$ \\ Faculty of Security Engineering, University of Zilina, 01026 Žilina, Slovakia; martin.boros@fbi.uniza.sk (M.B.); \\ lucia.figuli@fbi.uniza.sk (L.F.); andrej.velas@fbi.uniza.sk (A.V.) \\ * Correspondence: zuzana.zvakova@fbi.uniza.sk
}

Citation: Zvakova, Z.; Boros, M.; Figuli, L.; Velas, A. Evaluation Process of the Burglary Resistance When Explosives Are Used to Create an Opening in the Barriers. Symmetry 2021, 13, 1740. https://doi.org/ $10.3390 /$ sym 13091740

Academic Editors: Juan Luis García Guirao and Robert Wieczorek

Received: 19 July 2021

Accepted: 13 September 2021

Published: 18 September 2021

Publisher's Note: MDPI stays neutral with regard to jurisdictional claims in published maps and institutional affiliations.

Copyright: (c) 2021 by the authors. Licensee MDPI, Basel, Switzerland. This article is an open access article distributed under the terms and conditions of the Creative Commons Attribution (CC BY) license (https:// creativecommons.org/licenses/by/ $4.0 /)$.

\begin{abstract}
Burglary resistance expresses the time required to overcome the barriers to cause the damage in order to unlawfully enter a place for the purposes of stealing property or committing a felony (i.e., disruption of important assets, e.g., critical infrastructure). Damage to the object protection system means damage to the symmetry of the system-the balance between protection measures and security threats. Barriers are considered to be the walls of buildings or secure storage units (safe, safe, etc.), i.e., passive barriers that separate asset (protected value) from the security threat. The role of barriers in the security system is also to slow down the attack and create a time reserve for the intervention of a security service. There is no uniform approach to express the burglary resistance of such barriers using explosives; however, burglary by explosion are present. Explosives in the article are a tool that can be used by the offenders. The article uses mainly Delphi method and Saaty method. These methods have made it possible to identify and expertly evaluate scenarios for the use of explosives to break a barrier. Logical methods and interviews were also used. The result of the article is the identification and evaluation of the possibilities of using explosives to overcome barriers and expressing the blast burglary resistance of barriers. The universal assessment approach allows the inclusion of explosives to the burglary resistance protection system assessment schemes.
\end{abstract}

Keywords: burglary resistance; assets protection system; explosives; blast load

\section{Introduction}

Security is one of the basic human needs, on the second place in the famous Maslow pyramid of needs [1]. Undoubtedly, this is due to the need to protect life in prehistory and as well as the property of people nowadays. While in the past, people used primary mechanical barriers for their protection, over time they found that for an effective level of security, mechanical barriers that provide passive protection must be supplement by the active ingredient, as alarm systems or the human factor in the form of a guard [2-4]. Thanks to their properties and significance, mechanical barriers have found their stable place in the field of security of the building, despite the digitization and modernization of the active components of the protection system.

Mechanical barriers can be defined on the basis of their two basic properties, the deterrence or deceleration of the intruder. Deterrence can be understood as a purposeful activity in which a robust mechanical barrier acts-the fence has a repulsive character and the intruder reconsiders the attempt to overcome it. It is therefore the psychological influence of the owner. The second essential feature is the slowing down of the intruders for as long as possible so that the active components of the assets protection can detect them and prevent them from entering in the assets, or stealing the protected interest [5-7]. The basic component or parameter defining the deceleration is so called burglary resistance. Burglary resistance is one of the basic properties of mechanical barriers, the time required 
to overcome a barrier, to destruct it or to perforate a hole with the minimum defined dimensions. The burglary resistance can be calculated using the basic formula

$$
\Delta t=t 2-t 1
$$

where:

$\Delta t$-needed for breaking the mechanical burglar resistant barrier,

t2-time of breaking the mechanical burglar resistant,

t1-time of the starting of breaking the mechanical barrier.

The burglary resistance is also directly linked to the certification of mechanical barriers, where the certification authority attempts to create a breakthrough opening using predefined destructive means, linked to the security class, which the mechanical barrier should be certified for. The whole process is linked to a set of technical standards marked as EN 1627-30, while in these standards the procedure for the dynamic and static part of the test is gradually developed [8-11]. The opening is precisely defined in [11] and it must be possible to place one of the three basic templates in the shape of a rectangle, ellipse, or circle. In addition to the term of opening in technical standards dealing with the issue, we can also meet the term partial opening, which is bound only for secure storage units and its meaning is described in more detail in technical standard EN 1143-1, but due to the focus of the paper we will not devote attention to it.

According to [11], destructive tools are divided into six sets, established in accordance with the endurance class of mechanical barriers used in building protection, except for secure storage units. The first three groups are primarily powered by human energy and are mostly pliers, screwdrivers, saws, and other small tools. In the fourth set of tools, only a cordless drill is available, and only in the fifth and sixth set are the electrically driven destructive means available.

It is questionable to what extent the division is sufficient, based on several studies conducted at FSI UNIZA [12] or FAI TBU [13], because it is highly probable that the intruder will not use only the means prescribed by the standard, and therefore it would be appropriate to carry out, in addition to the standard certification test, real tests using various destructive means. Given the current global situation, it would be appropriate that the destructive tools could be appropriately added to the given groups, or the exact dimensions and weights of the destructive tools could be canceled from the groups.

However, as is obvious from real cases, one of the possibilities is, for example, the use of improvised explosive devices, to support interagency criminal cases. Between March 2018 and February 2019 in Manchester areas, a series of cash machine explosion burglaries were committed [14]. American U.S. Bomb Data Center (USBDC) collects information and intelligence about the investigation of bombings, arson, and the criminal use of explosives and states that 261 criminal cases were supported by USBDC nationwide in 2019 [15].

In the case of using explosives, the damage caused by the attempt to overcome could be much higher as well as the impact on the value of the property. It is therefore necessary to think about such a possibility in the project phase of security design of the assets, especially in the case of assets of specific importance $[16,17]$.

\section{Materials and Methods}

The basis for the elaboration of the paper was several scientific and professional publications from 1973 to the present. The initial knowledge also includes the basics of the explosion and its effects described by Henrych (1973) as well as technical standards focused on the burglar resistance of mechanical barriers.

The Delphi method [18] and the Saaty method $[19,20]$ were used as a priority in solving the problem in the identification of scenarios using the explosive charge to overcome the protection system as well as in the assignment of weights for individual scenarios. The group of experts met online, which made it possible to know the opinions of all experts in real time. A total of 25 members were part of the group of experts. The professional 
focus of the members of this group was in the field of risk management, object protection, burglar resistance of mechanical barriers, pyrotechnics in the civil and military sectors, and from the area protection against the effects of explosions. The Delphi method took two rounds to identify possible scenarios for overcoming elements of the building protection system. In the case of assigning weights to individual scenarios in the Saaty method, it took place in three rounds. After each round, the opinions were processed and submitted to the experts for free discussion. The anonymity of the individual opinions was ensured during the meeting. Finally, the members of the management team (authors of the paper) summarized the results and familiarized the group of experts.

This method of implementation was proved to be efficient and flexible. Communication with individuals was dynamic and managed without any problems.

Saaty pairwise comparison method $[19,20]$ was used to assign weights to individual scenarios. The scenarios were evaluated by a group of experts in terms of the applicability of the scenario and the time of its implementation. Attack time as an evaluation criterion for scenarios was selected as a necessary component of the burglary resistance evaluation process. The evaluation of the scenarios with regard to their applicability included a general expert assessment of the workability of the charges as well as the possibility of obtaining or constructing the charge. The assessment of the effectiveness of explosives against specific elements, like the case study, has not been examined.

The methodology for determining the weights was in accordance with the rules for using the Saaty method. The validity of the weights was verified by consistency ratio [19]. After assigning weights to individual scenarios, the geometric mean was determined and then the resulting weights of individual scenarios were calculated:

$$
v_{i}=G_{i} /\left(\sum(i=1) \wedge{ }^{*} G_{i}\right)
$$

where:

$v_{i}$ weight of scenario,

$\mathrm{G}_{\mathrm{i}}$ geometrical average.

Taking into account the general approach to the expression of burglar resistance, based on the time required to create a breakthrough opening using the selected tool, the rate of burglar resistance using explosives can be expressed by the coefficient of the total weight of the scenario:

$$
\mathrm{K}_{\mathrm{S}}=\mathrm{V}_{\mathrm{A}} * \mathrm{~V}_{\mathrm{T}} * 100
$$

where:

- $\quad \mathrm{K}_{\mathrm{S}}$ coefficient of the total weight of the scenario,

- $\quad \mathrm{V}_{\mathrm{A}}$ weight of application of scenario-determined by the Saaty method,

- $\quad \mathrm{V}_{\mathrm{T}}$ weight of the time of scenario realization-determined by the Saaty method.

For the relationship between the scenario coefficient and the breakthrough resistance, the rule applies that the higher the scenario coefficient, the lower the breakthrough resistance of the barrier. The following criteria for the general evaluation of the rate of burglar resistance can be used:

- rate of burglar resistance is very high for $\left.\mathrm{K}_{\mathrm{S}}<0 ; 0.3\right)$,

- rate of burglar resistance is high for $\mathrm{K}_{\mathrm{S}}<0.3 ; 0.5$ ),

- rate of burglar resistance is medium for $\left.\mathrm{K}_{S}<0.5 ; 1\right)$,

- rate of burglar resistance is low for $\left.\mathrm{K}_{\mathrm{S}}<1 ; \infty\right)$.

The effect of the explosion on assets near the explosion source is a complex problem and previous research can be found in [21-24]. Burglar resistance to attack using explosives includes:

- Type of perpetrator, their motivations, knowledge, abilities, and skills.

- The characteristics of the environment are important for the reflection of the pressure wave during an explosion. 
- Type of charge, its design affects the direction of pressure propagation during an explosion and its intensity.

- The mutual arrangement of the charge and of the material / element to be overcome speaks of the position of the charge relative to the destroyed element.

\subsection{Type of Perpetrator, Their Motivations, Knowledge, Abilities and Skills}

Preparation is necessary to overcome the elements of the protection system using explosives. For this reason, it can be ruled out that the act would be committed by a random perpetrator, or by an offender using only the basic (normal) range of tools [25-28]. Prerequisite for the use of explosives to overcome the object protection system is knowledge of the environment, i.e., knowledge of the disposition of the protected assets and the elements of the protection system. It is necessary to be able to use both a complete range of basic and special tools and equipment, as well as the possibility of using tools and equipment that can be described as non-standard.

The motivation of the offender may be profit for personal use or for a third party $[27,28]$. However, the motif can also be personal, e.g., revenge. The essence of the attack is always to create a way to gain a protected interest. In this use of explosives, we do not consider perpetrators whose aim is to destroy an assets using explosion, or to irreversibly damage it or kill people. Despite what is described above, such use of explosives cannot be ruled out in terrorist attacks, especially on elements of critical infrastructure and objects of special importance [29-31].

This type of attackers are therefore highly professional, which is reflected not only in the fact that they are able to use explosives, but also in the way to use it. Influence of the type of offender factor influencing the process of assessing the breakthrough resistance will be included in the choice of the type of charge and the method of its location.

\subsection{The Characteristics of the Environment Are Important for the Reflection of the Pressure Wave during an Explosion}

The general effects of the explosion on the surroundings and the impact of the explosion on buildings and people were addressed in their activities by [32-35]. In relation to the assessment of burglary resistance, it is necessary to perceive the characteristics of the environment due to the increment of pressure due to the reflection of the pressure wave (Figure 1) and subsequent undesired damage to other objects, but also due to the possibility of detecting the perpetrator.

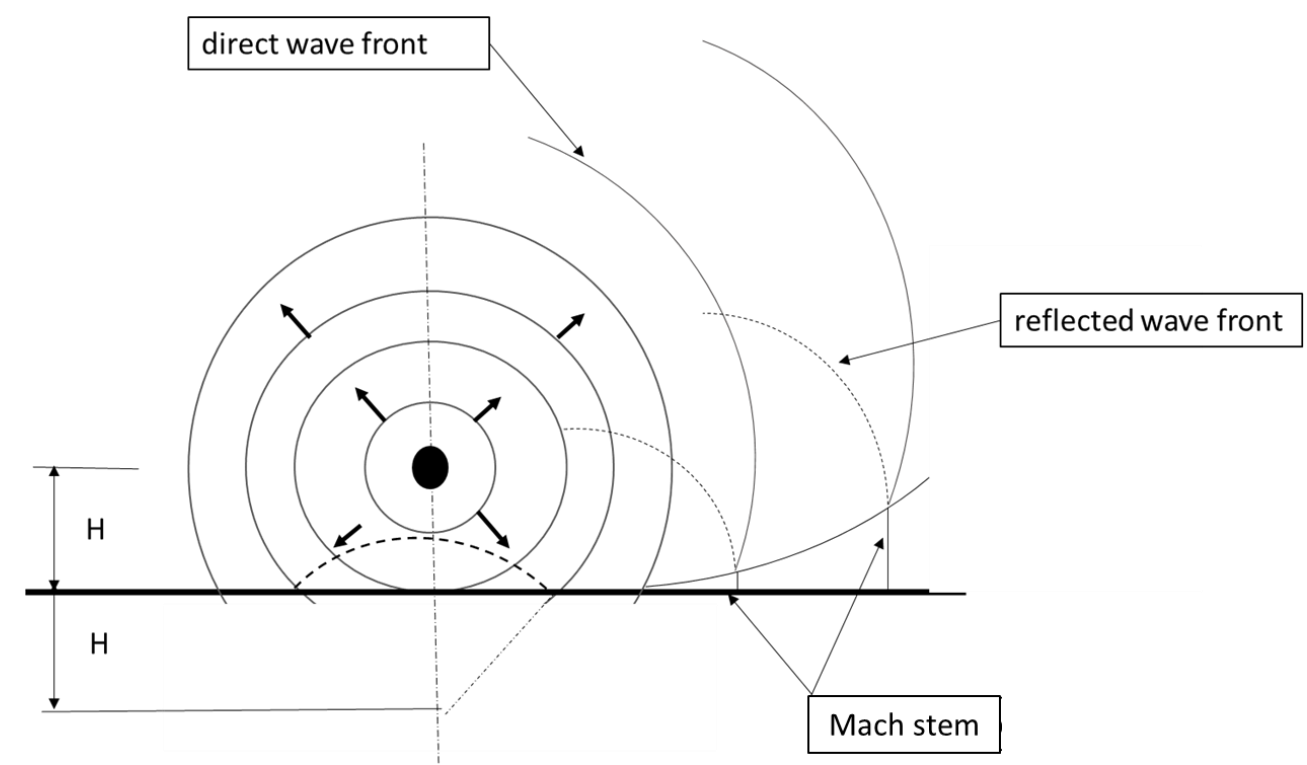

Figure 1. Schematic representation of the progressive position of wave fronts due to an explosive event [36]. 
The blast wave propagation was in detail analyzed in our previous research in [37]. The characteristics of the environment is a factor whose influence in the process of evaluation of the burglary resistance will be included in the choice of the type of charge and the method of its location. The perpetrator must therefore know the impact of the explosion on the surroundings and to plan the use of the charge in relation to the surroundings of the explosion site.

\subsection{Type of Charge, Its Design Affects the Direction of Pressure Propagation during an Explosion and Its Intensity}

The charges are categorized as concentrated charges, which represent the simplest type of charge in terms of construction. This type of charge is typical of its spherical or cube shape, i.e., a shape in which all dimensions are approximately the same. The explosion of the concentric charge is terminated on the entire surface of the charge at the same time and the energy is propagated in all directions equally. Linear charges, the shape of which is characterized by the fact that one dimension (length) significantly exceeds the other two dimensions (height and width). The height of the linear charge must not exceed its width. These charges generally have the shape of a cylinder of the desired length. The advantage is the even distribution of the explosive along the entire length of the destroyed element. The disadvantage of linear charges is the lower rate of utilization of the explosive energy of the used explosive. Various test were conducted previously to study the influence of charge shape on its effects (Figure 2). Figure 2 shows the different shapes of concentrated charges that were tested to investigate the effect of the shape of the charge on blast wave propagation [38-40]. During the tests, military explosives, industrial explosives, and home-made ANFO explosives were examined. The tests were carried out in an open area, therefore, the effect on objects around the site of the explosion has not been subject to research.

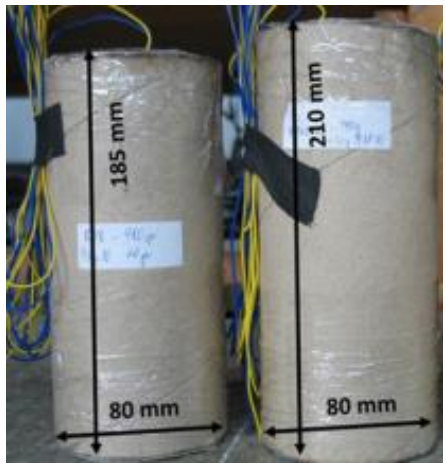

(a)

(b)

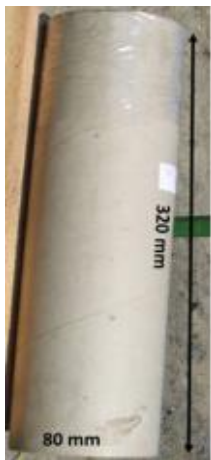

(c)

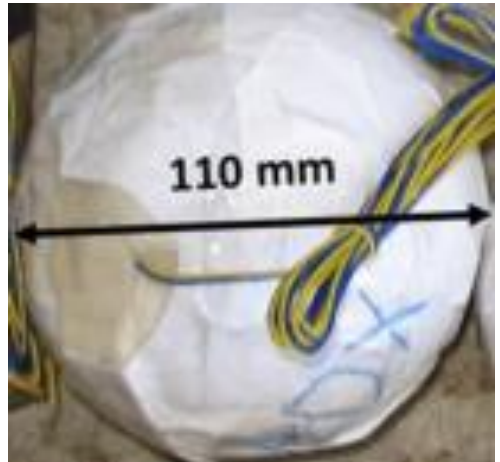

(d)

Figure 2. Different type of explosive charge from the experimental study: (a) RDX cylinder, (b) ANFO, (c) ammonium nitrate, (d) RDX sphere.

Concentrated and linear charges are equivalent in terms of their application to overcome the protection system [41,42].

Shaped charges are charges using the cavity effect of explosives [34]. A shaped charge is a charge with a hollow center, e.g., cone-shaped, which can be covered with a thin layer of metal - a cumulative insert. By their effects, the explosion acts perpendicular to the surface of the depression and, together with the molten metal, forms a shaped jet. This is characterized by high speed and penetration [36]. The effect of the shaped charge is thus many times higher in one direction than in the other.

At the point of contact of the front of the shaped jet and the material to be destroyed, dynamic pressures are generated that substantially exceed the strength of the material. A shaped charge is a charge with a cone-shaped cavity, which can be covered with a thin layer of metal. The effect of the explosion is perpendicular to the surface of the cavity. The explosion with its effects, together with its molten metal, creates a shaped beam. 
This is characterized by high speed and strong penetration. The shaped beam is formed depending on the distance from the charge. The smallest profile and the largest density and velocity reached in the focus, at a distance $f$ from the charge (Figure 5a). From this point, the shaped beam diverges, its profile increases, its density and velocity decrease [36]. In summary, the breakthrough effect of a shaped charge can be expressed as a function of the properties of the explosive, the shaped insert, and the shape of the explosive charge, the size, shape, and location of the charge, the properties of the package, and the properties of the target material.

Of the above-described types of charges, shaped charges are the most effective due to their ability to generate jet. The construction of the shaped charge [42] is not so demanding that a professional attacker cannot make it at home. However, there are restrictive conditions. The most important of these is that the explosives in the shaped charge are those whose detonation velocity is greater than $6000 \mathrm{~m} / \mathrm{s}$. In the case of explosives with a lower detonation rate, there would be no accumulation, resp. to create a shaped jet, but the effect of the explosion would be only directed. In the case of overcoming the protection system with explosives, the use of concentrated and linear charges cannot be ruled out. These are easier to make and place lower demands on the used explosive type. When concentrated and linear charges explode, the pressure spreads in all directions, so their efficiency can be increased by sealing and/or placing them in an opening.

\subsection{The Mutual Arrangement of the Charge and of the Material/Element to Be Overcome Speaks of} the Position of the Charge Relative to the Destroyed Element

The location of the charge near the object can be assumed in the case of objects with a high degree of security and perimeter monitoring. However, the charge would have to contain an amount of explosive corresponding to the distance between the site of the explosion and the element being destroyed [41,42]. Pressure wave generated in explosion would damage objects/elements around the source of explosion [43]. Such an attack would be ostentatious and unlikely given the possible extent of the damage.

Attaching the charge to the object. The charge can be placed at the element, either on the ground or above the ground, and the height of the charge has an effect on the reflection of pressure during the explosion [36] This type of attack assumes that the attacker has a sufficient amount of explosives. Enclosed charges are concentrated charges where the basic shape is a sphere or cube. Typically, all dimensions are approximately the same. These charges are not inserted in the destroyed material in any way. In the case of enclosed charges, the radius of effectiveness of the explosion must be equal to the thickness of the destroyed element (Figure 3), and at the same time the properties of the destroyed element must be taken into account.

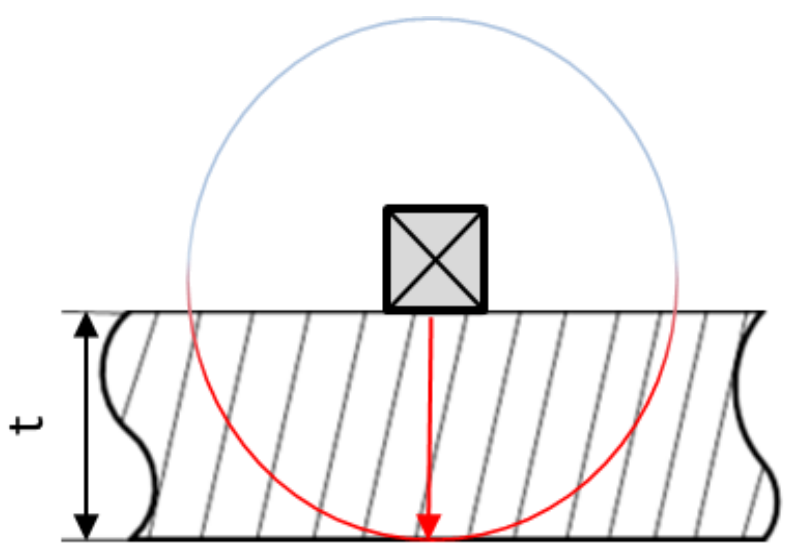

Figure 3. Relation between the radius of effectiveness of the enclosed charge and the thickness of the material. 
In the of case of breaking of durable elements, e.g., thick concrete and reinforced concrete walls, could generate a pressure of more than $150 \mathrm{kPa}$ at a distance of $2 \mathrm{~m}$ from the site of the explosion. This pressure would cause a large extent of damage and death of persons [41,44] (Figure 4).

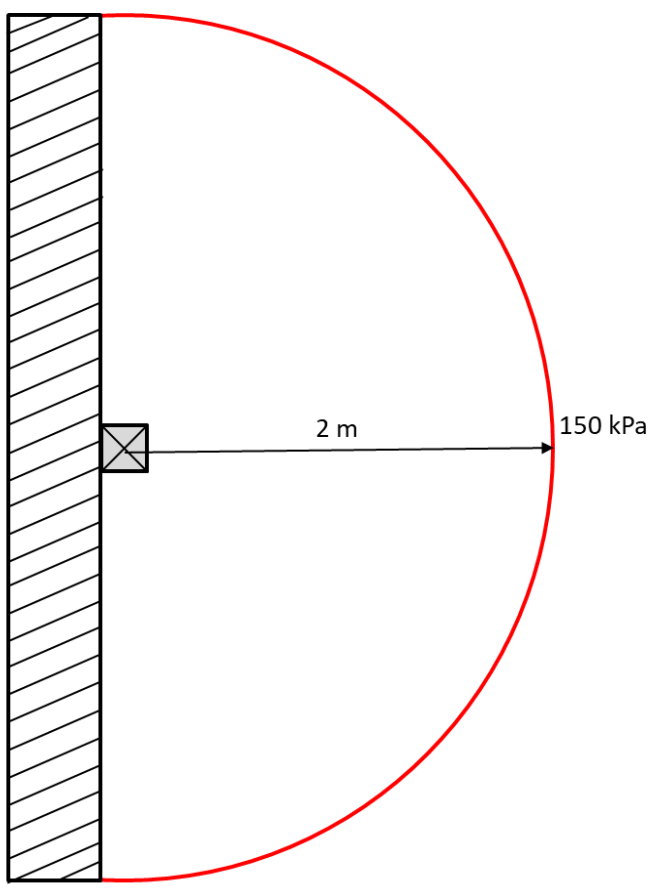

Figure 4. Pressure generated at the distance of $2 \mathrm{~m}$ from the explosion site when breaking of durable elements.

The enclosed charge can be sealed and thus partially direct the effect of the explosion. Even using the sealing of the charge, such use of explosives would again be ostentatious and endanger objects and people in the vicinity.

The charge can be placed in the destroyed element, respectively, in the opening created by attacker or in natural opening of the element.

A charge placed in an opening created by the attacker. Placing the charge into the hole created by the perpetrator in the building requires preparation-the creation of the hole and thus the use of other tools, respectively, complete toolkits. This preparation can attract unwanted attention to the perpetrator's actions and also affects the time taken to overcome the security feature. The opening formed can be sealed to resist and prevent the escape of explosive fumes, thus reducing the efficiency requirements of the explosive used in the charge. By creating the hole, the thickness of the destroyed element is reduced and thus the requirement for the radius of the explosion efficiency is reduced.

A charge can be placed in a hole that is as a natural part of the element, e.g., ventilation. It is an attack that uses the geometric shape, construction, and natural properties of the destroyed element. During its implementation, it is not necessary to prepare a hole and the charge placed in this way can be sealed and thus increase its effectiveness. The origin of the hole is important due to the duration of the attack, because the duration of the attack is part of the assessment of burglary resistance. From the point of view of the effectiveness of the explosion, it depends on the depth of the hole or its sealing, and not on its origin. The deeper the hole, the lower the workload requirements of the charge. From the point of view of the assessment of burglary resistance, the use of naturally occurring holes is more effective (for the attacker). In addition to the origin of the charge location, the depth of the charge placement is also important in assessing attack scenarios. Deeper placement of the charge reduces the demands on the amount of explosive, as it reduces the thickness of the destroyed material and helps to direct the pressure effect of the explosion. The charge can 
be placed below the surface of the element, at a depth of $1 / 3$ of the element thickness or at a depth of $1 / 2$ of the element thickness.

In the case of shaped charges (Figure 5a), four situations are relevant (Figure $5 b$ ). Situations 1 and 2 in Figure $5 b$ illustrate the use of a shaped charge design without a cumulative insert. In this case, we are talking about a directed charge, not a shaped charge. Situations 3 and 4 show the effectiveness of shaped charges with a cumulative insert and an explosive whose detonation velocity is higher than $6000 \mathrm{~m} / \mathrm{s}$.

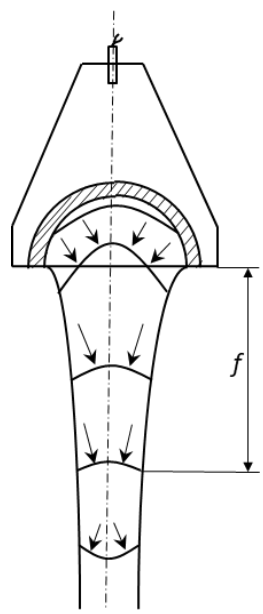

(a)

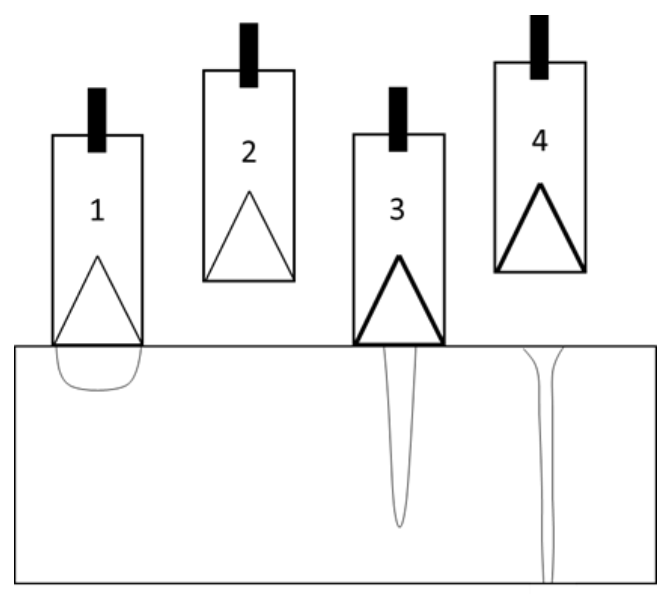

(b)

Figure 5. (a) Shaped charge scheme [36], (b) Directed effect of the explosion (1) (2) and cumulative effect of the explosion (3) (4) [35].

\section{Results}

Based on the types of charges and possible ways of their use in overcoming the protection system, we identified ten basic scenarios, as shown in Table 1.

Table 1. Scenarios of using explosives to overcome protection system.

\begin{tabular}{ccc}
\hline Scenario $\mathbf{N}^{\circ}$ & Scenario & Note \\
S1 & Near charge & \\
S2 & Attached charge & \\
S3 & Attached charge sealed & The charge deposition depth \\
S4 & Charge placed in hole & was neglected in the \\
S5 & Sealed charge placed in hole & assessment due to the same \\
S6 & Charge placed in natural cavity & applicability of the scenario. \\
S7 & Sealed charge placed in natural cavity & Directed charge \\
S8 & Shaped charge & \\
S9 & Shaped charge in standoff distance & \\
S10 & &
\end{tabular}

The identified scenarios were assessed by Saaty method from the point of view of the general applicability of the scenario (Table 2) and the general evaluation of the time of its implementation (Table 3).

The weights of the $\mathrm{V}_{\mathrm{A}}$ and $\mathrm{V}_{\mathrm{T}}$ scenarios include an expert evaluation of the time of the attack and an expert evaluation of the applicability of the scenario. The degree of breakthrough resistance (Table 4) is determined by calculation according to Equation (3). 
Table 2. Scenarios assessed by Saaty method from the point of view of the general applicability of the scenario.

\begin{tabular}{|c|c|c|c|c|c|c|c|c|c|c|c|c|}
\hline & S1 & S2 & S3 & S4 & S5 & S6 & S7 & S8 & S9 & S10 & $\begin{array}{c}\text { Geometric } \\
\text { Average }\end{array}$ & $\begin{array}{c}\text { Weight } \\
\text { V }_{\text {A }}\end{array}$ \\
\hline S1 & 1 & $1 / 4$ & $1 / 4$ & $1 / 7$ & $1 / 7$ & $1 / 7$ & $1 / 7$ & $1 / 7$ & $1 / 8$ & $1 / 9$ & 0.19 & 0.01 \\
\hline S2 & 4 & 1 & $1 / 3$ & $1 / 6$ & $1 / 6$ & $1 / 7$ & $1 / 6$ & $1 / 6$ & $1 / 8$ & $1 / 9$ & 0.27 & 0.015 \\
\hline S3 & 4 & 3 & 1 & $1 / 6$ & $1 / 6$ & $1 / 5$ & $1 / 6$ & $1 / 6$ & $1 / 8$ & $1 / 9$ & 0.35 & 0.019 \\
\hline S4 & 7 & 6 & 6 & 1 & $1 / 5$ & $1 / 2$ & $1 / 3$ & $1 / 5$ & $1 / 8$ & $1 / 9$ & 0.69 & 0.037 \\
\hline S5 & 7 & 6 & 6 & 5 & 1 & 5 & 4 & $1 / 4$ & $1 / 8$ & $1 / 9$ & 1.56 & 0.085 \\
\hline S6 & 7 & 5 & 5 & 2 & $1 / 5$ & 1 & $1 / 5$ & $1 / 4$ & $1 / 8$ & $1 / 9$ & 0.74 & 0.04 \\
\hline S7 & 7 & 6 & 6 & 3 & $1 / 4$ & 5 & 1 & $1 / 3$ & $1 / 8$ & $1 / 9$ & 1.16 & 0.063 \\
\hline S8 & 7 & 6 & 6 & 5 & 4 & 4 & 3 & 1 & $1 / 8$ & $1 / 9$ & 1.96 & 0.107 \\
\hline S9 & 8 & 8 & 8 & 8 & 8 & 8 & 8 & 8 & 1 & $1 / 9$ & 4.24 & 0.231 \\
\hline S10 & 9 & 9 & 9 & 9 & 9 & 9 & 9 & 9 & 9 & 1 & 7.22 & 0.393 \\
\hline SUM & & & & & & & & & & & 18.38 & 1 \\
\hline
\end{tabular}

Note: Scenario weight in pairwise comparison: from 1—equal importance to 9-extreme importance.

Table 3. Assessment by Saaty method from the point of the period of scenario realization.

\begin{tabular}{|c|c|c|c|c|c|c|c|c|c|c|c|c|}
\hline & S1 & $\mathrm{S} 2$ & S3 & $\mathrm{S} 4$ & S5 & S6 & S7 & S8 & S9 & S10 & $\begin{array}{c}\text { Geometric } \\
\text { Average }\end{array}$ & $\begin{array}{c}\text { Weight } \\
\mathrm{V}_{\mathrm{T}}\end{array}$ \\
\hline S1 & 1 & 3 & 4 & 8 & 9 & 3 & 4 & 3 & 3 & 3 & 3.51 & 0.234 \\
\hline S2 & $1 / 3$ & 1 & 3 & 8 & 9 & 2 & 4 & 3 & 3 & 3 & 2.63 & 0.175 \\
\hline S3 & $1 / 4$ & $1 / 3$ & 1 & 7 & 6 & 2 & 4 & 3 & 3 & 3 & 1.94 & 0.130 \\
\hline $\mathrm{S} 4$ & $1 / 8$ & $1 / 8$ & $1 / 7$ & 1 & 2 & $1 / 7$ & $1 / 6$ & 8 & 8 & 8 & 0.75 & 0.050 \\
\hline S5 & $1 / 9$ & $1 / 9$ & $1 / 6$ & $1 / 2$ & 1 & $1 / 7$ & $1 / 6$ & 9 & 9 & 9 & 0.67 & 0.045 \\
\hline S6 & $1 / 3$ & $1 / 2$ & $1 / 2$ & 7 & 7 & 1 & 2 & 2 & 2 & 2 & 1.52 & 0.101 \\
\hline S7 & $1 / 4$ & $1 / 4$ & $1 / 4$ & 6 & 6 & $1 / 2$ & 1 & 1 & 1 & 1 & 0.88 & 0.059 \\
\hline S8 & $1 / 3$ & $1 / 3$ & $1 / 3$ & 8 & 9 & $1 / 2$ & 1 & 1 & 1 & 1 & 1.03 & 0.069 \\
\hline S9 & $1 / 3$ & $1 / 3$ & $1 / 3$ & 8 & 9 & $1 / 2$ & 1 & 1 & 1 & 1 & 1.03 & 0.069 \\
\hline S10 & $1 / 3$ & $1 / 3$ & $1 / 3$ & 8 & 9 & $1 / 2$ & 1 & 1 & 1 & 1 & 1.03 & 0.069 \\
\hline \multicolumn{11}{|c|}{ SUM } & 14.97 & 1 \\
\hline
\end{tabular}

Note: Scenario weight in pairwise comparison: from 1-equal importance to 9-extreme importance.

Table 4. Representation of the rate of burglar resistance of protection system depending on the scenarios.

\begin{tabular}{cccc}
\hline Scenario $\mathbf{N}^{\circ}$ & Scenario & Ks & Rate of Burglar Resistance \\
\hline S1 & Near charge & 0.24 & Very high \\
S2 & Attached charge & 0.26 & Very high \\
S3 & Attached charge sealed & 0.25 & Very high \\
S4 & Charge placed in hole & 0.19 & Very high \\
S5 & Sealed charge placed in hole & 0.38 & High \\
S6 & Charge placed in natural cavity & 0.41 & High \\
S7 & Sealed charge placed in natural cavity & 0.37 & High \\
S8 & Directed charge & 0.73 & Medium \\
S9 & Shaped charge & 1.58 & Low \\
S10 & Shaped charge in standoff distance & 2.70 & Low \\
\hline
\end{tabular}

\section{Discussion}

The identified weights of the basic scenarios with the use of explosives to overcome the protection system are in accordance with the expected result. The position of the scenario "Charge placed in created hole" has a surprising effect. After closer examination of the results, we concluded that the scenario ended with the lowest weight due to the low probability of such an attack. This is because it is difficult to assume that a professional attackers would have a charge prepared and a set of tools for making a hole, would have enough time and the situation would allow them to place the charge in the prepared hole, and they would not seal the charge in the end. This finding also points to the fact that the members of the expert group, assigning weights to individual scenarios in terms of their applicability, also took into account the probability that the attack would be carried out in this way. 
The assessment of the degree of burglar resistance is a general qualitative expression. This general model can be adapted to a specific situation by taking into account situational factors. Situational factors are related to the type of protected object (importance for the operation of the state, society) and its security situation (method of control of the protected area, movement of people in the vicinity, built-up area, type of element to be overcome). Time is an important factor in evaluating burglar resistance and is important to answer the questions:

1. Will the attacker set up the charge on site or can he have it prepared in advance?

2. Does the situation allow for opening a hole for the charge placement? How fast can the attacker prepare the hole? What tools can he use?

3. How quickly can the attacker place and seal the charge?

4. At what distance from the place of attack is the space to hide the attacker?

The question of the time needed to implement the scenario opens up space for further research into the field of burglar resistance of the elements of the protection system.

\section{Conclusions}

The assessment of the degree of burglar resistance is a general qualitative expression, which is based on the experience of experts. The group of experts who cooperated in the evaluation was set up to cover the areas of risk management, security of assets, pyrotechnics, and burglar resistance.

The evaluation of the level of burglar resistance expressed in this way takes into account only optional factors of attacks and the situational side is neglected here. Evaluating the burglar resistance of a particular element, it is necessary to evaluate the feasibility of scenarios in relation to the type of protected assets and the time factor.

Scenarios sorted by weight from the highest weight of the scenario (lowest level of burglar resistance) to the lowest weight (highest level burglar resistance) are given in Table 5 .

Table 5. Attack scenarios sorted according to the level of burglar resistance.

\begin{tabular}{ccc}
\hline Scenario $\mathbf{N}^{\circ}$ & Scenario & $\begin{array}{c}\text { Rate of Burglar } \\
\text { Resistance }\end{array}$ \\
\hline S10 & Shaped charge in standoff distance & Low \\
S9 & Shaped charge & Low \\
S8 & Directed charge & Medium \\
S6 & Sealed charge placed in the natural cavity & High \\
S5 & Sealed charge placed in hole & High \\
S7 & Sealed charge placed in the natural cavity & High \\
S2 & Enclosed charge & Very high \\
S3 & Enclosed charge sealed & Very high \\
S1 & Near charge & Very high \\
S4 & Charge placed in hole & Very high \\
\hline
\end{tabular}

The implementation of the general model of burglar resistance assessment in the schemes of asset security assessment and design of protection systems allows to work with scenarios that include explosives among the tools that can overcome the protection system. Because technical standards do not calculate with this type of attack, it is a separate category of non-standard attacks.

The probability of such an attack increases with the value of the protected interest and with the possibility of home-made production of explosives. An attack can be expected especially in the case of critical infrastructure and other important objects for the functioning of the state or functioning of a company. Together with the possibility of home-made production of explosives and the construction of the charge, their use to overcome the system of protection of the object cannot be ruled out, even for less significant assets. However, it can be assumed that the method of carrying out the attack would be less sophisticated. 
Author Contributions: Conceptualization, Z.Z., M.B. and L.F.; Methodology, Z.Z. and A.V.; Validation, L.F. and Z.Z.; Formal analysis, A.V.; Investigation, Z.Z., M.B., A.V. and L.F.; Resources, Z.Z., M.B., A.V. and L.F.; Data curation, M.B. and L.F.; Writing-original draft preparation, Z.Z. and M.B.; Writing-review and editing, L.F. and A.V.; Visualization, L.F. and Z.Z.; Supervision, L.F.; Project administration, Z.Z.; Funding acquisition, A.V. and Z.Z. All authors have read and agreed to the published version of the manuscript.

Funding: This research was funded by University of Žilina, grant number KOR/1088/2020.

Institutional Review Board Statement: Not applicable.

Informed Consent Statement: Not applicable.

Data Availability Statement: Data sharing is not applicable to this article.

Acknowledgments: The article was supported by University of Žilina, grant number KOR/1088/2020.

Conflicts of Interest: The authors declare no conflict of interest.

\section{References}

1. Herve, L.G.; Sorin, M. A model of cooperative agent based on imitation and maslow's pyramid of needs. In Proceedings of the IEEE International Joint Conference on Neural Networks 2009, Atlanta, GA, USA, 14-19 June 2009; pp. $2347-2354$.

2. Soltes, V.; Stofkova, Z. Security as an aspect of the quality management in local self-government in age of globalization. In Proceedings of the 16th International Scientific Conference on Globalization and its Socio-Economic Consequences, Rajecke Teplice, Slovakia, 5-6 October 2016; pp. 2060-2067.

3. Lovecek, T.; Velas, A.; Kampova, K.; Mariš, L.; Mózer, V. Cumulative probability of detecting an intruder by alarm systems. In Proceedings of the International Carnahan Conference on Security Technology Proceedings 2013, Medellin, Colombia, 8-10 October 2013. [CrossRef]

4. Kampova, K.; Lovecek, T.; Rehak, D. Quantitative approach to physical protection systems assessment of critical infrastructure elements: Use case in the Slovak Republic. Int. J. Crit. Infrastruct. Prot. 2020, 30, 100376. [CrossRef]

5. Loveček, T.; Reitšpís, J. Projektovanie a Hodnotenie Systémov Ochrany Objektov (Design and Evaluation of Objects Protection Systems). Monograp; Žilinská Univerzita v Žiline-EDIS-Vydavatetel'stvo Žilinskej Univerzity: Žilina, Slovakia, 2011; 281p, ISBN 978-80-554-0457-8.

6. Mach, V.; Boros, M. Perimeter protection elements testing for burglar resistance. Key Eng. Mater. 2017, 755, 292-299. [CrossRef]

7. Mach, V.; Boros, M. Secure storage units testing for burglar resistance. Key Eng. Mater. 2017, 755, 340-345. [CrossRef]

8. Requirements and Classification. Pedestrian Doorsets, Windows, Curtain Walling, Grilles and Shutters-Burglar Resistance. EN 1627. In CENELEC, Brussels, Czech Equivalent Available on the Basis of a License for the Faculty of Security Engineering; BSI Standards: London, UK, 2011.

9. Burglar Resistance-Test Method for the Determination of Resistance under Static Loading. Pedestrian Doorsets, Windows, Curtain Walling, Grilles and Shutters. EN 1628. In CENELEC, Brussels, Czech Equivalent Available on the Basis of a License for the Faculty of Security Engineering; BSI Standards: London, UK, 2011.

10. Burglar Resistance-Test Method for the Determination of Resistance under Dynamic Loading. Pedestrian Doorsets, Windows, Curtain Walling, Grilles and Shutters.EN 1629. In CENELEC, Brussels, Czech Equivalent Available on the Basis of a License for the Faculty of Security Engineering; BSI Standards: London, UK, 2016.

11. Burglar Resistance-Test Method for the Determination of Resistance to Manual Burglary Attempts. Pedestrian Doorsets, Windows, Curtain Walling, Grilles and Shutters. EN 1630. In CENELEC, Brussels, Czech Equivalent Available on the Basis of a License for the Faculty of Security Engineering; BSI Standards: London, UK, 2016.

12. Siser, A.; Maris, L.; Rehak, D.; Pellowski, W. The use of expert judgement as the method to obtain delay time values of passive barriers in the context of the physical protection system. In Proceedings of the 52nd Annual IEEE International Carnahan Conference on Security Technology, Montreal, QC, Canada, 22-25 October 2018. [CrossRef]

13. Ivanka, J.; Navratil, P. Difference of cylindrical locks break resistance in the dependence on outdoor temperature. In Proceedings of the 54th International Conference on Experimental Stress Analysis, Srni, Czech Republic, 30 May-2 June 2016.

14. Greater Manchester Police. Five Men Have Been Jailed for over 45 Years after a Series of Cash Machine Explosion Burglaries. 2019. Available online: https://www.gmp.police.uk/news/greater-manchester/news/news/2019/november/five-men-havebeen-jailed-for-over-45-years-after-a-series-of-cash-machine-explosion-burglaries/ (accessed on 21 May 2021).

15. ATF. Fact Sheet-U.S. Bomb Data Center. 2021. Available online: https://www.atf.gov/resource-center/fact-sheet/fact-sheet-usbomb-data-center (accessed on 21 May 2021).

16. Lovecek, T.; Maris, L.; Siser, A. Security Systems Planning and Design of Objects Protection Systems; EDIS: Zilina, Slovakia, 2018; p. 286. ISBN 978-805-5414-829.

17. Lovecek, T.; Siser, A.; Maris, L. Use case of waterwork physical protection system robustness evaluation as a part of Slovak critical infrastructure. In Proceedings of the 52nd Annual IEEE International Carnahan Conference on Security Technology, Montreal, QC, Canada, 22-25 October 2018. [CrossRef]

18. Listone, H.A.; Turoff, M. The delphi method: Techniques and applications. J. Mark. Res. 1975, 13, 317. [CrossRef] 
19. Mu, E.; Pereyra-Rojas, M. Practical Decision Making - An Introduction to the Analytic Hierarchy Process (AHP) Using Super Decisions V2; Springler: Berlin/Heidelberg, Germany, 2017; ISBN 978-3-319-33861-3.

20. Saaty, T.L.; Vargas, L.G. Decision Making with the Analytic Network Process-Economic, Political, Social and Technological Applications with Benefits, Opportunities, Costs and Risks; Springler: Berlin/Heidelberg, Germany, 2013; ISBN 978-1-4614-7279-7.

21. Kerampran, S.; Arrigoni, M.; Locking, P. Blast Waves Propagation and Their Mitigation. Greener and Safer Energetic and Ballistic Systems, Military Technical Academy Publishing House. 2016. Available online: https:/ / hal-ensta-bretagne.archives-ouvertes. $\mathrm{fr} /$ hal-01714103/document (accessed on 21 May 2021).

22. Bedon, C.; Zhang, X.H.; Santos, F.; Honfi, D.; Kozłowski, M.; Arrigoni, M.; Lange, D. Performance of structural glass facades under extreme loads-Design methods, existing research, current issues and trends. Constr. Build. Mater. 2018, 163, 921-937. [CrossRef]

23. Bohanek, V.; Dobrilovič, M.; Škrlec, V. The efficiency of linear shaped charges. Teh. Vjesn. 2014, 21, 525-531.

24. Figuli, L.; Bedon, C.; Zvakova, Z.; Jangl, S. Dynamic analysis of a blast loaded steel structure. Procedia Eng. 2017, 199, 2463-2469. [CrossRef]

25. Wegerhoff, D.; Ward, T.; Dixon, L. A pluralistic approach to the definition, classification, and explanation of gangs. Aggress. Violent Behav. 2021, 58, 101546. [CrossRef]

26. Hofreiter, L. Manažment Ochrany Objektov; EDIS: Zilina, Slovakia, 2015; ISBN 978-80-554-1164-4.

27. Birkbeck, C.; Lafree, G. The situational analysis of crime and deviance. Annu. Rev. Sociol. 1993, 19, 113-137. [CrossRef]

28. Soltes, V.; Stofkova, K.R. The economic consequences of crime and other antisocial activities. In Proceedings of the CBU International Conference Proceedings, Praha, Czech Republic, 22-24 March 2017; pp. 443-447. [CrossRef]

29. Lovecek, T.; Velas, A.; Durovec, M. Level of protection of critical infrastructure in the Slovak republic. In Proceedings of the International Conference on Engineering Science and Production Management, Tatranská Štrba, Serbia, 16-17 April 2016; pp. 163-168.

30. Nyikes, Z.; Rajnai, Z. Big data, as part of the critical infrastructure. In Proceedings of the 13th International Symposium on Intelligent Systems and Informatics, Subotica, Serbia, 17-19 September 2015. [CrossRef]

31. Rehak, D.; Senovsky, P.; Hromada, M.; Lovecek, T. Complex approach to assessing resilience of critical infrastructure elements. Int. J. Crit. Infrastruct. Prot. 2019, 25, 125-138. [CrossRef]

32. Gati, J.; Kovacs, T. Metal hardness changing in case of explosive welding. In Proceedings of the 11th IEEE International Symposium on Applied Computational Intelligence and Informatics, Timisoara, Romania, 12-14 May 2016; pp. 157-160.

33. Kovacs, T.A.; Mhatre, U.; Nyikes, Z.; Enikő, B. Surface modification innovation for wear resistance increasing. In Proceedings of the 5th International Conference on Competitive Materials and Technology Processes, Miskolc-Lillafured, Hungary, 8-12 October 2019; p. 613. [CrossRef]

34. McLemore, R.H. Application of the shaped-charge process to petroleum production. In Drilling and Production Practice Toggle Menu; OnePetro: New York, NY, USA, 1947.

35. Galvani, A.H. Theory and Application of Sharped Charges; Lehigh University: Bethlehem, PA, USA, 1951.

36. Henrych, J. Dynamika Výbuchu a Její Užití; Academia: Praha, Czech Republic, 1973; p. 411.

37. Figuli, L.; Cekerevac, D.; Bedon, C.; Leitner, B. Numerical analysis of the blast wave propagation due to various explosive charges. Adv. Civ. Eng. 2020, 2020, 8871412. [CrossRef]

38. Figuli, L.; Kavický, V.; Zvaková, Z.; Maňas, P. Influence of homemade ammonium nitrate and fuel oil explosives charge shapes on blast wave propagation. Int. J. Comput. Methods Exp. Meas. 2016, 4, 213-220. [CrossRef]

39. Figuli, L.; Kavický, V.; Jangl, Š.; Zvaková, Z. Comparison of the efficacy of homemade and industrially made Anfo explosives as an improvised explosive device charge. Commun. Sci. Lett. Univ. Žilina 2018, 20, 23-27.

40. Kavický, V.; Figuli, L.; Jangl, Š.; Zvaková, Z. Analysis of the field test results of ammonium nitrate: Fuel oil explosives as improvised explosive device charges. In Structures under Shock and Impact; WIT Press: Southampton, UK, 2014; pp. $297-309$.

41. Jangl, S.; Kavický, V. Ochrana Pred Účinkami Výbuchov Výbušnín a Nástražných Výbušných Systémov; Jana Kavická-KAVICKY: Oščadnica, Slovakia, 2012; p. 294. ISBN 9788097110802.

42. Bauer, K. Príručka Pre Strelmajstrov a Technických Vedúcich Odstrelov. Slovak Company for Blasting and Drilling Work; Slovenská spoločnost' pre trhacie a vŕtacie práce: Banská Bystrica, Slovakia, 2014; p. 334. ISBN 9788097026585.

43. Ivanco, M.; Trajkovsky, J.; Figuli, L.; Erdélyiová, R. Determination of blast resistance of selected structural elements. In Proceedings of the Conference on Dynamics of Civil Engineering and Transport Structures and Wind Engineering, Donovaly, Slovak, 25-29 May 2020; p. 313. [CrossRef]

44. Makovička, M.; Janovský, B. Příručka Protivýbuchové Ochrany Staveb; Czech Technology—Publishing House ČVUT in Prague: Prague, Czech Republic, 2008; ISBN 978-01-04090-4. 